\title{
First record on the biology of Sarcophaga (Bulbostyla) (Diptera, Sarcophagidae)
}

\author{
Pierre-Marc Brousseau', Marjolaine Giroux², I. Tanya Handa' \\ I Département des sciences biologiques, Université du Québec à Montréal, 141, avenue du Président-Kennedy, \\ Montréal, QC, H2X 1Y4, Canada 2 Montréal Insectarium / Space for life, 4581, rue Sherbrooke Est, Mon- \\ tréal, QC, H1X 2B2, Canada
}

Corresponding author: Marjolaine Giroux (marjolaine.giroux@elf.mcgill.ca)

Academic editor: M. Hauser | Received 12 September 2019 | Accepted 18 November 2019 | Published 5 February 2020

http://zoobank.org/80AA62AC-300C-40DC-932A-03736D3E9954

Citation: Brousseau P-M, Giroux M, Handa IT (2020) First record on the biology of Sarcophaga (Bulbostyla) (Diptera, Sarcophagidae). ZooKeys 909: 59-66. https://doi.org/10.3897/zookeys.909.46488

\begin{abstract}
A first breeding record for Sarcophaga (Bulbostyla) cadyi Giroux \& Wheeler on the American giant millipede Narceus americanus (de Beauvois) (Spirobolida, Spirobolidae) is reported. Digital photographs of the terminalia of $S$. (B.) cadyi and of Sarcophaga (Bulbostyla) yorkii Parker are also provided.
\end{abstract}

\section{Keywords}

feeding behaviour, flies, host, millipedes, Nearctic Region, Spirobolidae

\section{Introduction}

Sarcophaga Meigen is a large and diverse genus comprising about 890 valid species worldwide (Buenaventura et al. 2017). In Canada, 39 species are currently known including 21 species recorded in Quebec (Pape 1996; Dahlem and Naczi 2006; Giroux and Wheeler 2010). Adult flies of Sarcophaga feed on various resources including sugar, carrion and dung. The main resources of the larvae are dead arthropods, snails and small vertebrates which they can use as scavengers, parasitoids or predators (Pape 1996; Coupland and Barker 2004; Mello-Patiu 2016). Within this genus, the recently described subgenus Bulbostyla Giroux \& Wheeler comprises nine species restricted to North and South America. It differs from other Sarcophaga mainly by characters of the 
male genitalia (Giroux and Wheeler 2010). The ecology of Bulbostyla species remains little known, although most specimens were collected on hilltops (Giroux and Wheeler 2010). No feeding records have previously been documented for larvae.

Here, we present the first observation of an interaction between the flesh fly $S$. (Bulbostyla) cadyi Giroux \& Wheeler and the American giant millipede Narceus americanus (de Beauvois) (Spirobolida, Spirobolidae). We also present digital photographs of the male terminalia of both species of Bulbostyla found in the province of Quebec $(S$. (B.) cadyi and $S$. (B.) yorkii Parker) and photographs of the female external terminalia of $S$. (B.) cadyi.

\section{Materials and methods}

A dead $N$. americanus colonized by eight sarcophagid larvae was collected on August 20 , 2017. The millipede was found on the forest floor $\left(45^{\circ} 33.18^{\prime} \mathrm{N}, 73^{\circ} 18.30^{\prime} \mathrm{W}\right)$ at Mont-Saint-Bruno National Park in southern Quebec. The millipede and the larvae of $S$. cadyi were brought to the laboratory and kept at constant room temperature $\left(-20{ }^{\circ} \mathrm{C}\right)$ in a small plastic container with garden soil. Once adult flies emerged, they were killed in the freezer and preserved in $70 \%$ alcohol. In order to be morphologically identified, they were rinsed twice in $100 \%$ ethyl acetate, then dried and pinned.

The specimens of $S$. (B.) yorkii were collected using a hand-held entomological net at the summit of Mont Rigaud $\left(45^{\circ} 27.96^{\prime} \mathrm{N}, 74^{\circ} 19.56^{\prime} \mathrm{W}\right.$, summers of 2007 and 2017 ) and of Mont-Saint-Bruno $\left(45^{\circ} 33.12^{\prime} \mathrm{N}, 73^{\circ} 19.68^{\prime} \mathrm{W}\right.$, summer 2010). Those specimens were killed using ethyl acetate fumes and pinned shortly afterwards.

The habitus photographs (Figs 1-4) were taken using a Nikon D810 DSLR camera with Nikon Micro-Nikkor $200 \mathrm{~mm} \mathrm{f} / 4$ lens on a Manfrotto 454 micrometric positioning sliding plate. Lighting was provided by two Nikon SB-25 flash units with a Cameron Digital diffusion photo box. Adobe Photoshop Elements 13 was used as post-processing software. Photographs of the terminalia and genitalia were taken with an Olympus DP27 camera mounted with stereoscope SZX16. Images were captured and stacked using Helicon Focus 7 before being enhanced using Adobe Photoshop CC (version 20.0) (Adobe Systems, Mountain View, CA).

To solidify species identity, a leg of some specimens of $S$. (B.) cadyi and $S$. (B.) yorkii were submitted to LifeScanner (http://lifescanner.net/) and others to the Canadian Centre for DNA Barcoding for DNA barcoding. It was only possible to obtain sequences for $S$. (B.) cadyi. Those sequences were compared and analysed using the Barcode of Life Data (BOLD: http://boldsystems.org/) System ID Engine (Ratnasingham and Hebert 2007). Individual sequences from the successful specimens are publicly available via GenBank accession codes MK585627-MK585630. They can also be retrieved from BOLD in the public dataset DS-SARCOPH (https://doi.org/10.5883/DS-SARCOPH).

The terminology of the terminalia follows Buenaventura and Pape (2017). All voucher specimens are deposited in Insectarium de Montréal's scientific collection (IMQC). 

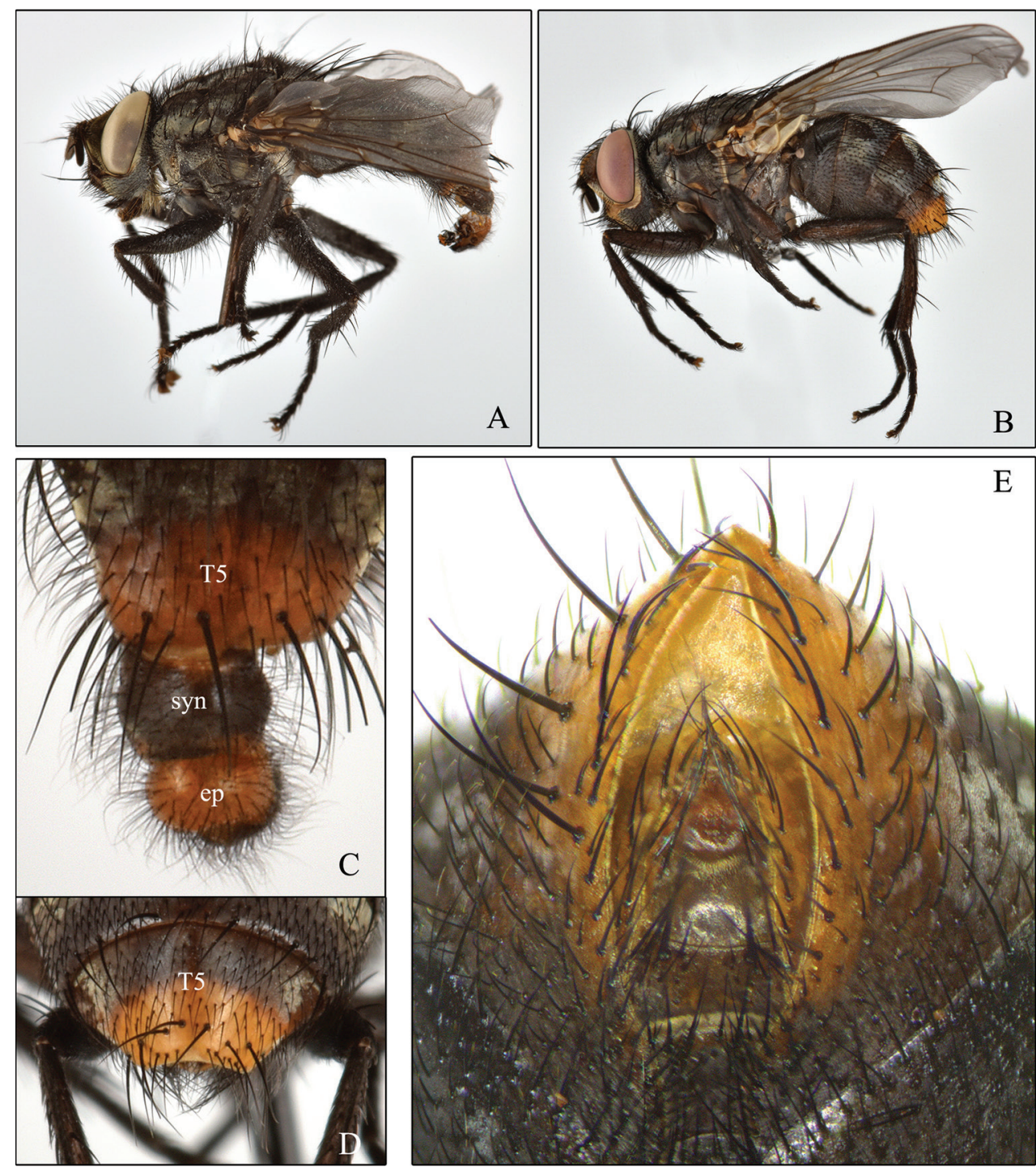

Figure I. Sarcophaga (Bulbostyla) cadyi A male habitus B female habitus $\mathbf{C}$ male tergite 5 (T5), syntergosternite 7+8 (syn) and epandrium (ep), dorsal D female tergite 5 (T5), dorsal $\mathbf{E}$ female postabdomen, ventral.

\section{Results and discussion}

We present the first breeding record for a species of Bulbostyla and the first mention of their larvae developing in a spirobolid millipede. We also present the first mention of a Sarcophaga species showing a feeding interaction with a millipede in North America, and the second worldwide after the European species Sarcophaga (Myorhina) iulicida Pape (Pape 1990a). 

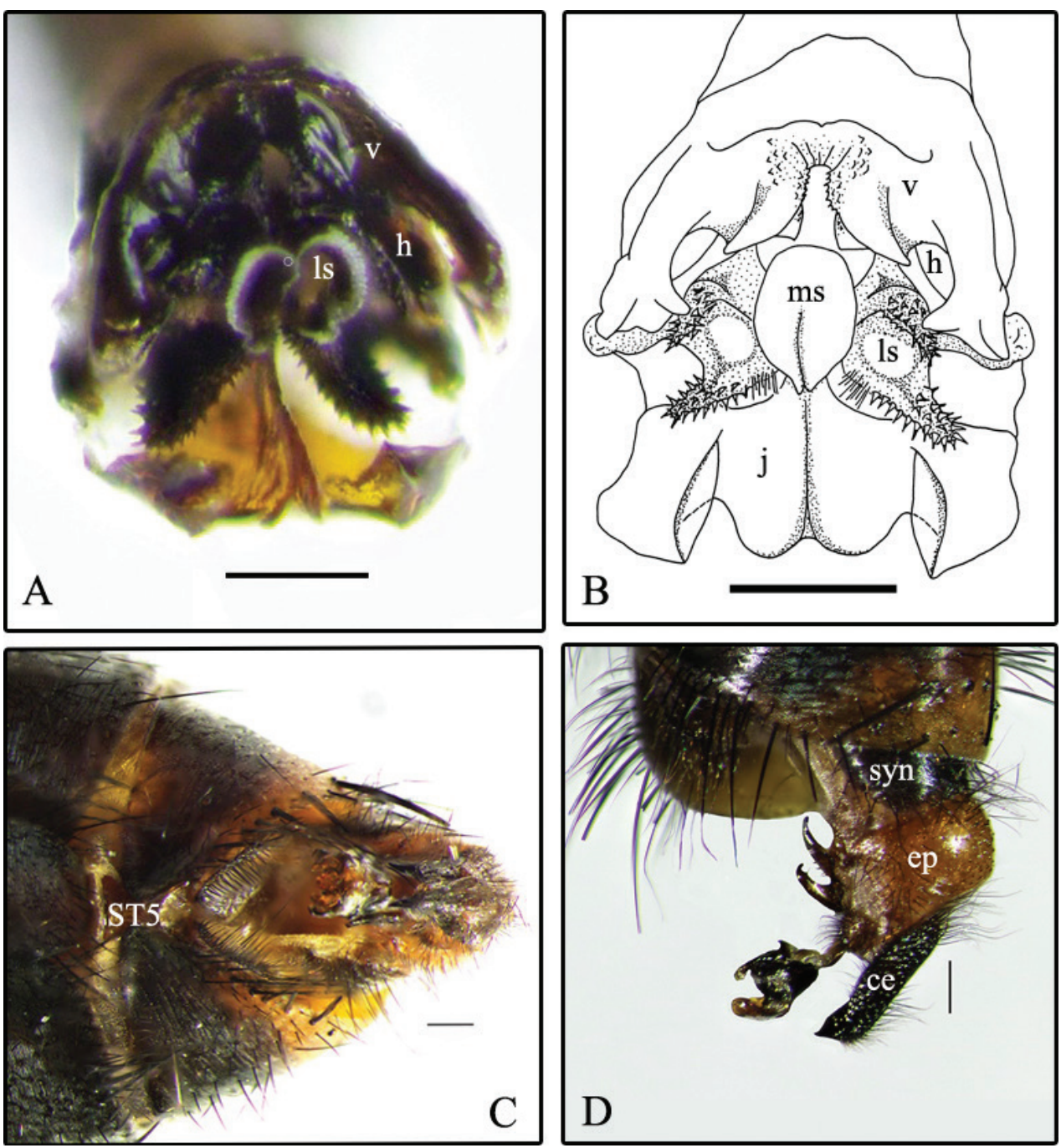

Figure 2. Sarcophaga (Bulbostyla) cadyi A distiphallus, anterior B distiphallus, anterior (from Giroux and Wheeler 2010) C male postabdomen, ventral D male postabdomen, left lateral. Abbreviations: j, juxta; ls, lateral stylus; ms, median stylus; h, harpes; v, vesica; syn, syntergosternite 7+8; ep, epandrium; ce, cercus; ST5, sternite 5. Scale bars: $0.2 \mathrm{~mm}(\mathbf{A}-\mathbf{B}), 0.5 \mathrm{~mm}$ (C-D).

Only three dipteran families (Sarcophagidae, Phoridae, Sciomyzidae) have been reported as parasitoids of diplopods (Hash et al. 2017). Within the Sarcophagidae, the species Blaesoxipha beameri Hall (Pape 1994) and species of the genus Spirobolomyia Townsend have been bred exclusively from spirobolid millipedes (Aldrich 1916; Pape 1990b, 1996) in North America. However, it is likely that species of this genus are not true millipede parasitoids. All observations of larviposition by Spirobolomyia species were on injured hosts with wounds large enough for the larva to enter (Hash et al. 2017). 


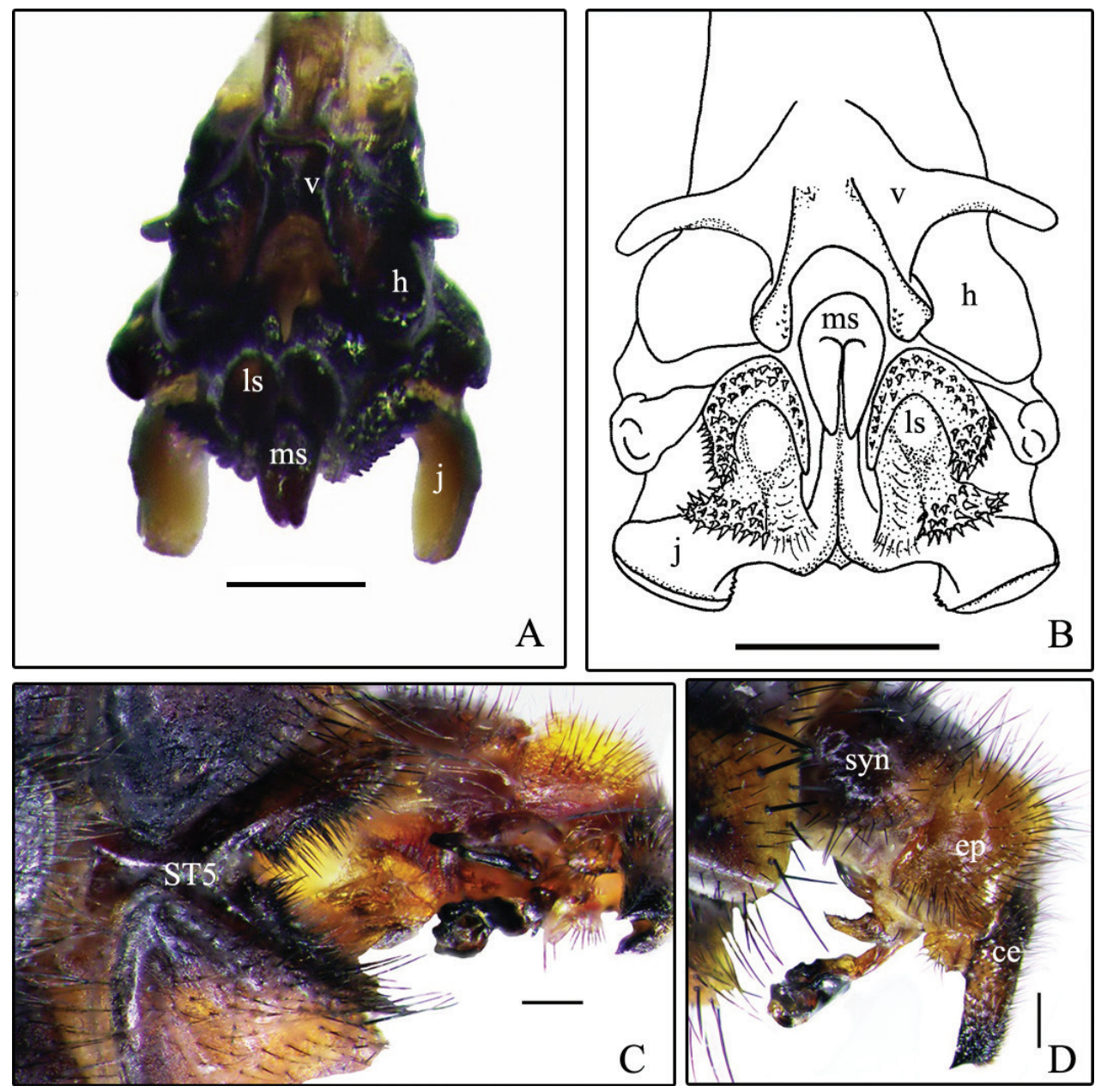

Figure 3. Sarcophaga (Bulbostyla) yorkii A distiphallus, anterior B distiphallus, anterior (from Giroux and Wheeler 2010) C male postabdomen, ventral D male postabdomen, left lateral. Abbreviations: j, juxta; ls, lateral stylus; ms, median stylus; h, harpes; v, vesica; syn, syntergosternite 7+8; ep, epandrium; ce, cercus; ST5, sternite 5. Scale bars: $0.2 \mathrm{~mm}$ (A-B), $0.5 \mathrm{~mm}$ (C-D).

We did not observe the larviposition of $S$. (B.) cadyi on $N$. americanus, which was already dead and colonized by the last instar larvae when we found it. Thus, we do not know if the spirobolid millipede was healthy, injured or already dead upon arrival of the female sarcophagid fly. In this sense, further investigations are needed to be able to determine the larval feeding habits of $S$. (B.) cadyi. The larvae pupated around August $25^{\text {th }}$. They pupated inside the millipede rather than exiting and pupating in the surrounding soil. It is unclear if this behaviour was due to laboratory conditions, or if it is also displayed in nature. Four males and four females emerged two weeks later, between 7 and 11 September 2017. 

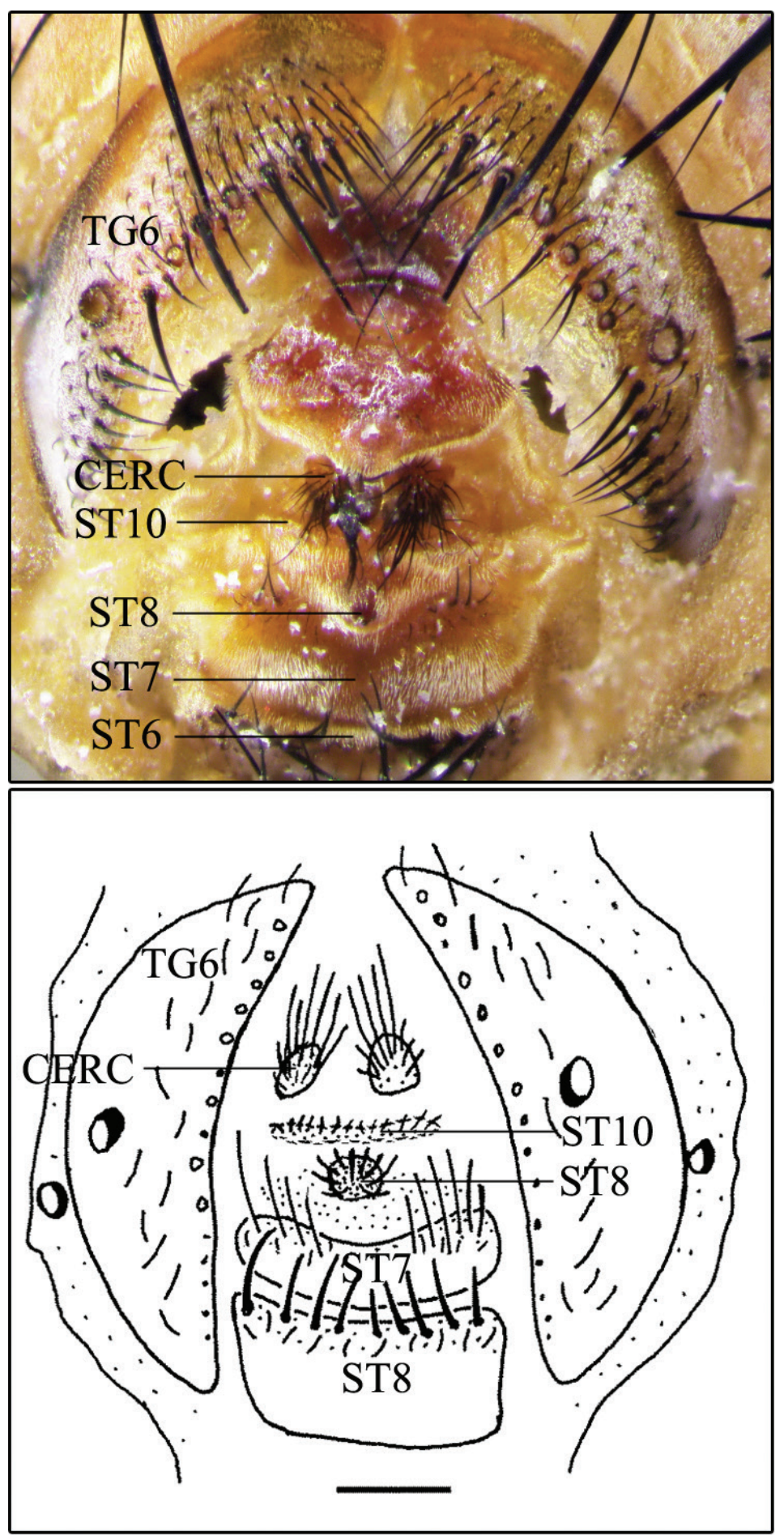

Figure 4. Sarcophaga (Bulbostyla) cadyi A female external terminalia, dorsoventral B female external terminalia, dorsoventral (from Giroux and Wheeler 2010). Abbreviations: cerc, cerci; st, sternite; tg, tergite. Scale bars: $0.5 \mathrm{~mm}(\mathbf{A}-\mathbf{B})$. 
Descriptions and an identification key for males of $S$. (B.) cadyi and $S$. (B.) yorkii can be found in Giroux and Wheeler (2010). However, in order to help in the identification of these species, some digital photographs are provided here: the habitus of $S$. (B.) cadyi, male and female (Fig. 1A, B); the postabdomen of a $S$. (B.) cadyi male (Figs $1 \mathrm{C}, 2 \mathrm{C}, \mathrm{D}$ ) and female (Fig. 1E) as well as the one of a $S$. (B.) yorkii male (Fig. 3C, D). Male and female specimens of both species have tergite 5 with an orangeyellow posterior half or third (sometimes entirely yellow) and a row of strong setae forming a semi circle that spreads on the apical third (Fig. 1C-E). The male cerci and syntergosternite $7+8$ are darker than the epandrium (Figs 1C, 2D, 3D). The window on male sternite 5 is almost even with the rest of the base (Figs 2C, 3C). The male distiphallus of both species as well as the external terminalia of female $S$. (B.) cadyi were digitally photographed (Figs 2A, 3A, 4A) and illustrations (Figs 2B, 3B, 4B) were added for a better understanding of their structural morphology.

\section{Acknowledgments}

We thank Maxim Larrivée for support and René Limoges (Insectarium de Montréal) for the habitus photographs, Alexandra Cecan and Karine Thivierge (Laboratoire de Santé Publique du Québec) for training and access to the stereomicroscope and photography equipment and Jade Savage (Bishop's University) for the sequencing of some specimens. We also thank Emilie Desjardins for collecting various N. americanus samples and Nathalie Rivard for permission to collect in the Parc national du Mont-Saint-Bruno. This research was funded by a Natural Sciences and Engineering Research Council of Canada Discovery Grant to ITH and by the Insectarium de Montréal to MG.

\section{References}

Aldrich JM (1916) Sarcophaga and allies in North America. The Thomas Say Foundation of the Entomological Society of America 1: 1-301. https://doi.org/10.5962/bhl.title.8573

Buenaventura E, Pape T (2017) Phylogeny, evolution and male terminalia functionality of Sarcophaginae (Diptera: Sarcophagidae). Zoological Journal of the Linnean Society 183 (4): 808-906. https://doi.org/10.1093/zoolinnean/zlx070

Buenaventura E, Whitmore D, Pape T (2017) Molecular phylogeny of the hyperdiverse genus Sarcophaga (Diptera: Sarcophagidae), and comparison between algorithms for identification of rogue taxa. Cladistics 33(2): 109-133. https://doi.org/10.1111/cla.12161

Coupland JB, Barker GM (2004) Diptera as predators and parasitoids of terrestrial gastropods, with emphasis on Phoridae, Calliphoridae, Sarcophagidae, Muscidae and Fanniidae. In: Barker GM (Ed.) Natural Enemies of Terrestrial Molluscs. CAB International, Wallingford, 85-158. https://doi.org/10.1079/9780851993195.0085

Dahlem GA, Naczi RFC (2006) Flesh flies (Diptera: Sarcophagidae) associated with North American pitcher plants (Sarraceniaceae), with description of three new species. Annals 
of the Entomological Society of America 99(2): 218-240. https://doi.org/10.1603/00138746(2006)099[0218:FFDSAW]2.0.CO;2

Giroux M, Wheeler TA (2010) Systematics of Bulbostyla, a new subgenus of Sarcophaga Meigen, and change of status for Robackina Lopes (Diptera: Sarcophagidae). Zootaxa 2553(1):3559. https://doi.org/10.11646/zootaxa.2553.1.2

Hash JM, Millar JG, Heraty JM, Harwood JF, Brown BV (2017) Millipede defensive compounds are a double-edged sword: natural history of the millipede-parasitic genus Myriophora Brown (Diptera: Phoridae). Journal of Chemical Ecology 43(2): 198-206. https:// doi.org/10.1007/s10886-016-0815-7

Mello-Patiu CA (2016) Family Sarcophagidae. Zootaxa 4122(1): 884-903. https://doi. org/10.11646/zootaxa.4122.1.75

Pape T (1990a) Two new species of Sarcophaga Meigen from Madeira and mainland Portugal (Diptera: Sarcophagidae). Tijdschrift voor Entomologie 133(1): 39-42. http://biostor.org/ reference/49964

Pape T (1990b) Revisionary notes on American Sarcophaginae (Diptera: Sarcophagidae). Tijdschrift voor Entomologie 133(1): 43-74. https://archive.org/details/cbarchive_48786_revisionarynotesonamericansarc1990/page/n2

Pape T (1994) The world Blaesoxipha Loew, 1861 (Diptera: Sarcophagidae). Entomologica Scandinavica, Supplement 45: 1-247.

Pape T (1996) Catalogue of the Sarcophagidae of the world (Insecta: Diptera). Memoirs on Entomology 8: 1-557.

Ratnasingham S, Hebert PDN (2007) The Barcode of Life Data System (http://www.barcodinglife.org). Molecular Ecology Notes 7(3): 355-364. https://doi.org/10.1111/j.14718286.2007.01678.x 